\title{
Article \\ Boswellia serrata Extract as an Antibiofilm Agent against Candida spp.
}

\author{
Petr Jaroš ${ }^{1}$, Maria Vrublevskaya ${ }^{2}$, Kristýna Lokočová ${ }^{2, *}$, Jana Michailidu ${ }^{2}$, Irena Kolouchová ${ }^{2}$ @D and \\ Kateřina Demnerová ${ }^{1}$ \\ 1 Department of Biochemistry and Microbiology, University of Chemistry and Technology, \\ 16628 Prague, Czech Republic; petr.jaros@vscht.cz (P.J.); katerina.demnerova@vscht.cz (K.D.) \\ 2 Department of Biotechnology, University of Chemistry and Technology, 16628 Prague, Czech Republic; \\ maria.vrublevskaya@vscht.cz (M.V.); jana.michailidu@vscht.cz (J.M.); irena.kolouchova@vscht.cz (I.K.) \\ * Correspondence: kristyna.lokocova@vscht.cz
}

check for updates

Citation: Jaroš, P.; Vrublevskaya, M.; Lokočová, K.; Michailidu, J.; Kolouchová, I.; Demnerová, K. Boswellia serrata Extract as an Antibiofilm Agent against Candida spp. Microorganisms 2022, 10, 171. https://doi.org/10.3390/ microorganisms10010171 Academic Editors: László Majoros and Elisabetta Blas

Received: 12 November 2021 Accepted: 11 January 2022 Published: 13 January 2022 Publisher's Note: MDPI stays neutral with regard to jurisdictional claims in published maps and institutional affiliations.

Copyright: (c) 2022 by the authors. Licensee MDPI, Basel, Switzerland. This article is an open access article distributed under the terms and conditions of the Creative Commons Attribution (CC BY) license (https:// creativecommons.org/licenses/by/ $4.0 /)$.

\begin{abstract}
The use of antibiotics or antifungals to control infections caused by pathogenic microorganisms is currently insufficiently effective because of their emerging resistance. Thanks to the ability of microorganisms to form a biofilm and thus increase their resistance to administered drugs even more, modern medicine faces the task of finding novel substances to combat infections caused by them. In this regard, the effects of essential oils or plant extracts are often studied. Among the relatively neglected plants is Boswellia serrata, which has a high content of biologically active boswellic acids. In this study, we focused on one of the most common nosocomial infections, which are caused by Candida species. The most common representative is C. albicans, although the number of infections caused by non-albicans species has recently been increasing. We focused on the antifungal activity of Boswellia serrata extract Bioswellix against planktonic and adhering cells of Candida albicans, Candida parapsilosis and Candida krusei. The antifungal activity against adhering cells was further explored by determining the metabolic activity of cells (MTT) and determining the total amount of biofilm using crystal violet. Boswellic acid-containing plant extract was shown to suppress the growth of a suspension population of all tested Candida species. Boswellia serrata extract Bioswellix was most effective in inhibiting C. albicans biofilm formation.
\end{abstract}

Keywords: Candida albicans; Candida krusei; Candida parapsilosis; boswellic acid; fluconazole; biofilm

\section{Introduction}

Many diseases caused by pathogenic and opportunistic pathogens are very difficult to treat with conventionally used drugs, antibiotics or antifungals, mainly due to the ability of microorganisms to form a biofilm and thus gain greater resistance to drugs [1]. Medical disciplines are not the only area where the occurrence of biofilms poses significant problems and complications [2]. Biofilms can also be found in various industries-they are involved in the corrosion of metals, reduce the efficiency of industrial heat exchangers [3] and are also a problem in the food industry [4]. We can often encounter the use of a variety of chemicals and detergents to remove the biofilm, such as hydroxides [5] or using new natural biologically active substances such as alkaloids, coumarins, saponins, tannins, quinones [6], phenols [7] and others. Natural agents also include boswellic acids, which are present in the resins of Boswellia serata and belong to a large group of biologically active pentacyclic triterpenes [6]. The major substance in this plant is acetyl-11-keto-ß-boswellic acid. Boswellic acids have significant activity against a number of inflammatory diseases, such as cancer, arthritis, chronic colitis, ulcerative colitis, Crohn's disease and bronchial asthma $[8,9]$.

New pharmacological studies have shown that in addition to anti-inflammatory effects, these compounds regulate the immune system, inhibit leukotriene synthesis, have antioxidant properties and protect the liver $[10,11]$. They further lower blood sugar [12] 
and triglycerides [13] and have a positive effect on memory [10]. They are thus used to prevent [14] and treat Alzheimer's disease [15]. In addition to the above-mentioned health-promoting properties, boswellic acids are also monitored for significant antimicrobial activity [16]. Studies have shown the antimicrobial activity of B. serrata against G+ bacteria [17] and antifungal activity against C. albicans [18-21]. Boswellic acids have been shown in in vitro studies and animal models to act as non-competitive inhibitors of 5-lipoxygenase, inhibiting DNA, RNA and protein synthesis [22], and they significantly reduce the degradation of glycosaminoglycan [23].

Yeast species of the genus Candida are considered to be the most common human pathogens under clinical conditions (e.g., periodontal tissues, formation of biofilm on any artificial materials in human niches, such as catheters, dentures, etc.). Although in most cases candidiasis is caused by the yeast C. albicans, other pathogenic species involved in this infection, such as C. parapsilosis, C. glabrata and C. tropicalis, have become increasingly common in recent decades [24]. C. parapsilosis is generally considered to be one of the least virulent yeasts, although it is currently a common species [25]. Azoles with antifungal activity, especially fluconazole, are still a major means of therapy against Candida infections. Their activity consists in the inhibition of lanosterol-14-alpha-demethylase, an enzyme involved in the basic step of ergosterol biosynthesis [26]. C. glabrata and C. krusei show high levels of resistance to fluconazole and other antifungals [27]. However, clinically important antifungal agents such as fluconazole or amphotericin B, flucytosine, echinocandins [28], itraconazole [2] or ketoconazole have not been found to be as effective against $C$. albicans biofilm than against suspended cells, and the concentrations required to reduce cell metabolic activity in biofilm are 5 to 8 times higher than the corresponding minimum inhibitory concentrations (MICs) [29].

Strains of C. albicans resistant to azole antibiotics inhibiting ergosterol biosynthesis occur under clinical conditions due to long-term use of these antibiotics. The mechanisms of resistance of $C$. albicans biofilms to fluconazole, but also to the newly used voriconazole, depend on the ongoing phase of biofilm formation. While efflux pumps are dominant in the early stages of formation, changes in sterol composition are typical for the middle and maturation phases of the biofilm $[30,31]$. C. albicans regulates the morphological conversion of the cells to a filamentous form, which is an important virulence factor in this yeast and biofilm formation via the quorum sensing system [32]. Our study addressed the antimicrobial effect of Boswellia serrata extract Bioswellix and its influence on the formation and stability of the biofilm of Candida albicans ATCC 2091, Candida krusei CCM 8271 and Candida parapsilosis CCM 8260.

\section{Materials and Methods}

\subsection{Antimicrobials}

Bioswellix (Interpharma Slovakia), an extract from Boswellia serrata resin, containing $35 \%$ of the most effective pentacyclic triterpenes acetyl- $\beta$-boswellic acid (ABA) and 3acetyl-11-keto- $\beta$-boswellic acid (AKBA), was used to test the antimicrobial activity of boswellic acids. Solutions containing boswellic acid were prepared by diluting them with dimethyl sulfoxide (DMSO), $40 \%$ ethanol or a given growth medium and were used in final concentrations ranging from 1 to $500 \mathrm{mg} \mathrm{L}^{-1}$. Fluconazole was dissolved in appropriate culture media and used at final concentrations ranging from 1 to $100 \mathrm{mg} \mathrm{L}^{-1}$.

\subsection{Microorganisms}

C. albicans ATCC 2091, C. krusei CCM 8271 and C. parapsilosis CCM 8260 originated from the Czech Collection of Microorganisms of Masaryk University in Brno. All strains were stored as cryopreserves in $50 \%$ glycerol at $-70^{\circ} \mathrm{C}$. 


\subsection{Cultivation of Microorganisms}

C. albicans, C. parapsilosis and C. krusei were cultured in YPD medium $\left(20 \mathrm{~g} \mathrm{~L}^{-1} \mathrm{D}\right.$ glucose anhydrous, Penta, Czech Republic; $20 \mathrm{~g} \mathrm{~L}^{-1}$ peptone, Difco Laboratories, Detroit, MI, USA; and $10 \mathrm{~g} \mathrm{~L}^{-1}$ yeast extract Carl Roth, Karlsruhe, Germany). Cultivation was performed for $48-72 \mathrm{~h}$ on an orbital shaker at $30^{\circ} \mathrm{C}$ and $100 \mathrm{~min}^{-1}$.

2.4. Assay of Minimum Inhibitory Concentrations (MIC) of Antimicrobials for Suspension Yeast Populations Using a Bioscreen C Microculture Device

The determination of $\mathrm{MIC}_{50}$ (the lowest concentration at which $50 \%$ inhibition of suspension growth occurs after $24 \mathrm{~h}$ ) is considered an important value expressing the susceptibility of planktonic cells to antimicrobial agents [33]. After culturing the microorganisms (see above), the inoculum was centrifuged $\left(10 \mathrm{~min}, 10^{\circ} \mathrm{C}, 9000 \times g\right)$ and $30 \mu \mathrm{L}$ of inoculum $\left(\mathrm{OD}_{600 \mathrm{~nm}}=0.100\right)$, and solutions of biologically active substances, were pipetted into each well of a microtiter plate (Labsystems, Helsinki, Finland). The maximum concentration of dimethyl sulfoxide or ethanol in the well did not exceed $1 \%$ and $2.5 \%$, respectively (solvents at this concentration did not affect the culture). The wells were then filled with the appropriate complex medium to the required volume of $320 \mu \mathrm{L}$. Cultivation was performed in a Bioscreen $\mathrm{C}$ for $24 \mathrm{~h}$ at $30^{\circ} \mathrm{C}$.

\subsection{Biofilm Formation}

The inoculum was centrifuged $\left(10 \mathrm{~min}, 10^{\circ} \mathrm{C}, 9000 \times \mathrm{g}\right)$, and its optical density was adjusted $\left(\mathrm{OD}_{600 \mathrm{~nm}}=0.800\right)$. Then, $210 \mu \mathrm{L}$ of the inoculum was transferred to a 96-well microtiter plate (TPP AG, Trasadingen, Switzerland). The cultivation of Candida yeasts was performed for $24 \mathrm{~h}$ at a temperature of $30^{\circ} \mathrm{C}$ and $150 \mathrm{~min}^{-1}$. After that, a solution of Bioswellix or fluconazole was pipetted (the total well volume was $280 \mu \mathrm{L}$ ) to monitor the effect of biologically active substances on the initial adhesion of cells. In the case of monitoring the effect of the substances on biofilm eradication, the substances were added only after $24 \mathrm{~h}$ ( or $48 \mathrm{~h}$ ) of biofilm cultivation without any antimicrobials added. After washing the wells three times with $200 \mu \mathrm{L}$ of physiological saline $(0.9 \% \mathrm{NaCl}$ (aq); Penta, Prague, Czech Republic), the culture continued in the presence of antimicrobials for another $24 \mathrm{~h}$.

All experiments were performed in 8 parallels. At the end of the culture, the contents of the wells were aspirated, and the wells were washed three times with physiological saline, and then images were taken using a Cellavista apparatus (SynenTec, Elmshorn, Germany).

\subsection{Quantification of Biofilm by Crystal Violet (CV) Staining and MTT}

The total biomass content, including extracellular structures of cells adhering to the surface of the entire microtiter plate, was determined by the crystal violet staining method. Crystal violet binds to negatively charged extracellular molecules, cell surface molecules, DNA and polysaccharides as well as proteins in the extracellular matrix [34]. The procedure was taken over and modified according to Sabaeifard et al. [35]. An amount of $200 \mu \mathrm{L}$ of a $0.1 \%$ filtered crystal violet solution (Carl Roth, Germany) was pipetted into each well, and the cells were stained for $20 \mathrm{~min}$. After washing the wells twice with saline, the wells were filled with $200 \mu \mathrm{L}$ of $96 \%$ ethanol (Penta, Czech Republic). After $10 \mathrm{~min}, 100 \mu \mathrm{L}$ volume from each well was transferred to a microtiter plate (Gamma Group, Ostrava, Czech Republic), and the color intensity was measured at $580 \mathrm{~nm}$.

As a complement to total biofilm biomass determination, the metabolic activity of the cells in biofilm was assessed using MTT. The methodology available in the current literature by Riss et al. [36] was used to determine the metabolic activity of the biofilm. At the end of the biofilm culture, the wells were washed three times with $200 \mu \mathrm{L}$ of saline. After that, $60 \mu \mathrm{L}$ of $57.4 \mathrm{mg} \mathrm{mL}^{-1}$ glucose solution (anhydrous glucose; Penta, Czech Republic) was pipetted into each well, plus $50 \mu \mathrm{L}$ of a $1 \mathrm{~g} \mathrm{~L}^{-1}$ solution of MTT (3-(4,5dimethyl-thiazol-2-yl)-2,5-diphenyltetrazolium bromide; Thermo Fisher Scientific, USA). 
Reaction was allowed to proceed for $1 \mathrm{~h}$ at $30^{\circ} \mathrm{C}$ on an orbital shaker $\left(150 \mathrm{~min}^{-1}\right)$. Then, $100 \mu \mathrm{L}$ of elution solution (4 parts of dimethylformamide with 6 parts of $2 \%(v / v)$ acetic acid in phosphate buffer saline) was pipetted into each well, and dodecyl sodium sulfate $(160 \mathrm{~g} / \mathrm{L})$ was dissolved in this solution. After vigorous mixing $\left(230 \mathrm{~min}^{-1} ; 30 \mathrm{~min}\right), 100$ $\mu \mathrm{L}$ of the solution was taken into a 96-well plate (Gamma Group, Czech Republic) and measured spectrophotometrically at a wavelength of $570 \mathrm{~nm}$.

\subsection{Determining the Minimum Concentration of Biofilm Inhibitors (MBIC)}

The minimum biofilm inhibitory concentration $\left(\mathrm{MBIC}_{50}\right)$ was determined (procedure modified from Paldrychova et al. [37]) as the lowest concentration that causes at least 50\% inhibition of the viability of formed biofilm (metabolic activity after a $24 \mathrm{~h}$ cultivation) in the presence of a biologically active agent. The metabolic activity was determined by the MTT (2,3-bis (2-methoxy-4-nitro5-sulfophenyl)-5-[(phenylamino) carbonyl]-2H-tetrazolium hydroxide) assay. Aliquots of $200 \mu \mathrm{L}$ (total volume) of yeast suspension $\left(\mathrm{A}_{600 \mathrm{~nm}}=0.6\right.$; corresponding to $10^{7}$ cells per $\mathrm{ml}$ ), obtained from the inoculum cultivation described above, were cultivated in YPD medium in the presence of the biologically active agent in a polystyrene 96-well microtiter plate (TPP AG, Trasadingen Switzerland) for $24 \mathrm{~h}$ at $30{ }^{\circ} \mathrm{C}$ in an orbital shaker $\left(150 \mathrm{~min}^{-1}\right)$. Concentration ranges were $0-100 \mathrm{mg} \mathrm{L}^{-1}$ for fluconazole and $0-500 \mathrm{mg} \mathrm{L}^{-1}$ for Bioswellix.

Controls without agent were also included. Each experiment was performed in eight replicates.

\subsection{Statistical Analysis}

Dixon's $Q$ test was performed to detect outliers in datasets obtained by the crystal violet staining and the MTT assay. The significance of the difference between control and antimicrobial-treated samples was determined by one-way analysis of variance (ANOVA) and Tukey's HSD test.

\section{Results and Discussion}

Opportunistically pathogenic and pathogenic microorganisms have long posed a major threat to humanity because they cause a variety of diseases. Although many synthetic anti-inflammatory drugs such as steroids, non-steroidal anti-inflammatory drugs (NSAIDs) and immunosuppressants are well established for use in various types of disease, their long-term use is limited by related side effects or the development of microbial resistance to these drugs $[12,38,39]$. The need for safe, readily available and effective treatment of various types of diseases leads to the study of herbal medicines. Many medicinal plants have been successfully used in the treatment of inflammation since ancient times and have been used in modern medicine in pharmaceutical form [40,41]. Conventionally, antifungals such as fluconazole are used to control diseases caused by the genus Candida. Fluconazole is a fungistatic agent whose mechanism of action is inhibition of the activity of fungal cytochrome P450-dependent C- $14 \alpha$-demethylase that results in the inhibition of biosynthesis of ergosterol, which is part of the fungal cell membranes and the most important structural membrane sterol. Disruption of ergosterol synthesis damages the cell membrane of the pathogen by inhibiting its growth and replication [42]. In the human body, fluconazole is metabolized more slowly due to its chemical structure, has a lower effect on the synthesis of human sterols and is therefore suitable for systemic use. Currently, there are two main products on the Czech market containing fluconazole as an active substance-Diflucan and Mycomax [43].

Biologically active substances isolated from natural sources do not promote the development of microbial resistance and are relatively effective even at low concentrations. Medicinal plants and their chemical components are used to treat a number of inflammatory diseases. Many chemical constituents of plant origin such as alkaloids, tannins, flavonoids, terpenoids, glycosides, carotenoids and saponins are said to have anti-inflammatory properties $[44,45]$. Compared with synthetically prepared molecules, these substances are also 
effective in eradicating extracellular polymeric structures [46]. Boswellic acids, alone or in combination with antibiotics, can be an example of the search for a positive effect of natural substances [47]. Boswellic acids and their derivatives have anti-inflammatory, anti-cancer, immunomodulatory, anti-asthmatic, antibacterial and anti-rheumatic properties [48] and function as anti-inflammatory agents [49].

While there are studies, both in vivo and in vitro, on the effect of boswellic acids on tissue cells [50-52] or on their anti-inflammatory [53,54] or anticancer effect [55], studies on their effect on microbial strains, especially eukaryotes, are lacking.

We compared the antifungal activity of Boswellia serrata extract Bioswellix with fluconazole. The antimicrobial effect of boswellic acids-containing solution was investigated on three species of Candida, both in suspension culture and against biofilm growth. The effect of the solvent used on the antimicrobial activity of Boswellia serrata extract Bioswellix was also investigated (Table 1). The ineffectiveness of the substances dissolved in the medium on suspension cells was probably due to the limited solubility of the active antimicrobials in the aqueous solution [56]. A solution of Boswellia serrata extract Bioswellix in DMSO proved to be the most effective, and therefore further experiments were performed with this solvent.

Table 1. Minimum inhibitory concentrations $\left(\mathrm{MIC}_{50}\right)$ of Bioswellix and fluconazole for C. albicans ATCC 2091, C. parapsilosis CCM 8260 and C. krusei CCM 8271.

\begin{tabular}{cccc}
\hline \multirow{2}{*}{$\mathbf{M I C}_{\mathbf{5 0}}\left(\mathbf{m g ~ L}^{-1}\right)$} & \multicolumn{3}{c}{ Microorganism } \\
\cline { 2 - 4 } & C. parapsilosis CCM 8260 & C. krusei CCM 8271 & C. albicans ATCC 2091 \\
\hline Bioswellix (EtOH) & 200 & 280 & 250 \\
Bioswellix (DMSO) & 80 & 120 & 20 \\
Bioswellix (medium) & $500^{\dagger}$ & $500^{\dagger}$ & $500^{\dagger}$ \\
Fluconazole & 20 & 35 & 50 \\
\hline
\end{tabular}

${ }^{\dagger}$ has not been determined up to the above concentration.

The sensitivity of Candida cells to the effects of antimicrobials depends not only on the concentration of these agents but also on other factors, such as the type of medium, incubation time and temperature [57]. There are basically two media type approaches used: a richer medium such as YPD medium [58] or Sabouraud medium [59] to create favorable conditions for the growth of yeast or low glucose and nutrient media such as RPMI medium [60].

In our study, we used the same medium (YPD) for both types of culture (suspension cells and biofilm) to allow favorable growth of the microorganisms and to allow comparison of the MIC and MBIC values. As the study was aimed at initial evaluation of the potential of boswellic acid as an anticandidal agent, we used model strains and model favorable conditions to ascertain their potential, with intended follow-up studies aimed at the clinical environment (with clinical Candida isolates and appropriate media) and other industrial applications, such as antifouling in the food industry, which would pose a nutrient-rich environment.

Bioswellix $\left(\mathrm{MIC}_{50}=20 \mathrm{mg} \mathrm{L}^{-1}\right)$ showed the highest inhibitory effect on the suspension population of C. albicans ATCC 2091 (Table 1). The highest $\mathrm{MIC}_{50}$ value was reached for C. krusei CCM 8271. The MIC values of Boswellia serrata extract Bioswellix found in our study for various members of the genus Candida were in accordance with the literature since the MICs of natural substances range in the tens [61-63] or hundreds of $\mathrm{mg} \mathrm{L}^{-1}$ [64-68]. Weckesser et al. [69] dealt with the effect of boswellic acids on yeasts of the genus Candida, but the MIC was not determined in the tested concentration range of $0.2-100 \mathrm{mg} \mathrm{L}^{-1}$. Several studies investigated the effect of boswellic acids on bacterial biofilm, such as $E$. faecalis and S. epidermidis [21], and the acids were also tested for their inhibitory effect on periodontal biofilm formation [70] or for suppression of skin and nail infections [71]. 
For the antifungal fluconazole, we found a $\mathrm{MIC}_{50}$ value in the range of $20-50 \mathrm{mg} \mathrm{L}^{-1}$ depending on the tested species. The efficacy of the azole-based antifungal agents used varies greatly depending on the strain tested and its specific sensitivity, and it ranges from $\mathrm{mg} \mathrm{L}^{-1}$ to tens of $\mathrm{mg} \mathrm{L}^{-1}[72,73]$.

The minimum inhibitory concentration of biofilm $\left(\mathrm{MBIC}_{50}\right)$ was determined by MTT assay (Table 2), as the metabolic activity of cells of selected Candida strains was monitored at the same time. We did not observe any significant effect of fluconazole on the biofilm of the studied yeasts. At antifungal concentration of $100 \mathrm{mg} \mathrm{L}^{-1}$, the metabolic activity of the cells decreased only slightly (with the exception of Candida parapsilosis strain CCM 8260 , in which the metabolic activity decreased by 50\%). Maiolo et al. [72] have shown that concentrations higher than $1000 \mathrm{mg} \mathrm{L}^{-1}$ should be used to inhibit biofilm formation (MBIC).

Table 2. Minimum biofilm inhibitor concentrations $\left(\mathrm{MBIC}_{50}\right)$ of Bioswellix and fluconazole for $C$. albicans ATCC 2091, C. parapsilosis CCM 8260 and C. krusei CCM 8271.

\begin{tabular}{cccc}
\hline \multirow{2}{*}{ MBIC $_{50}\left(\mathrm{mg} \mathrm{L}^{-1}\right)$} & \multicolumn{3}{c}{ Microorganism } \\
\cline { 2 - 4 } & C.parapsilosis CCM 8260 & C. krusei CCM 8271 & C. albicans ATCC 2091 \\
\hline Bioswellix (DMSO) & $500^{+}$ & $500^{+}$ & 100 \\
Fluconazole & 75 & $100^{+}$ & $100^{+}$ \\
\hline
\end{tabular}

${ }^{\dagger}$ has not been determined up to the above concentration.

Research on the active substances of the Boswellia plant deals with the antibiofilm effects of isolated essential oils on Candida yeasts rather than with boswellic acids or resin extracts of this plant. Schillaci et al. [20] confirmed the antibiofilm activity of essential oil derived from Boswellia papyrifera and Boswellia rivae on Staphylococcus aureus, Staphylococcus epidermidis and C. albicans. Other studies that have addressed the antimicrobial effects of essential oils on yeast of the genus Candida also describe their good activity against biofilms [74]. The main components of essential oils derived from the genus Boswellia are monoterpene substances such as $\alpha$ thujone, myrcene and limonene, not boswellic acids.

Figures 1 and 2 demonstrate the antibiofilm activity of Bioswellix and the antifungal fluconazole in terms of metabolic activity and total biomass content of Candida. The metabolic activity of the Candida krusei strain was not affected even by the concentration of $500 \mathrm{mg} \mathrm{L}^{-1}$ Bioswellix (Figure 1). Bioswellix had the greatest antibiofilm effect on the yeast $C$. albicans, in which the metabolic activity of the biofilm decreased by $30 \%$ to $60 \%$ depending on the concentration used (1-500 $\left.\mathrm{mg} \mathrm{L}^{-1}\right)$. The decrease in the content of total biomass at all monitored concentrations also corresponded to this. The antifungal fluconazole had a negligible effect on the metabolic activity of the C. krusei biofilm. In general, the effectiveness of inhibiting biofilm formation was weaker for fluconazole than for boswellic acids contained in the Boswellia serrata extract Bioswellix (Figure 2). According to Butassi et al. [75], the increase in biofilm resistance to antifungals is associated with a significant decrease in total ergosterol content. 

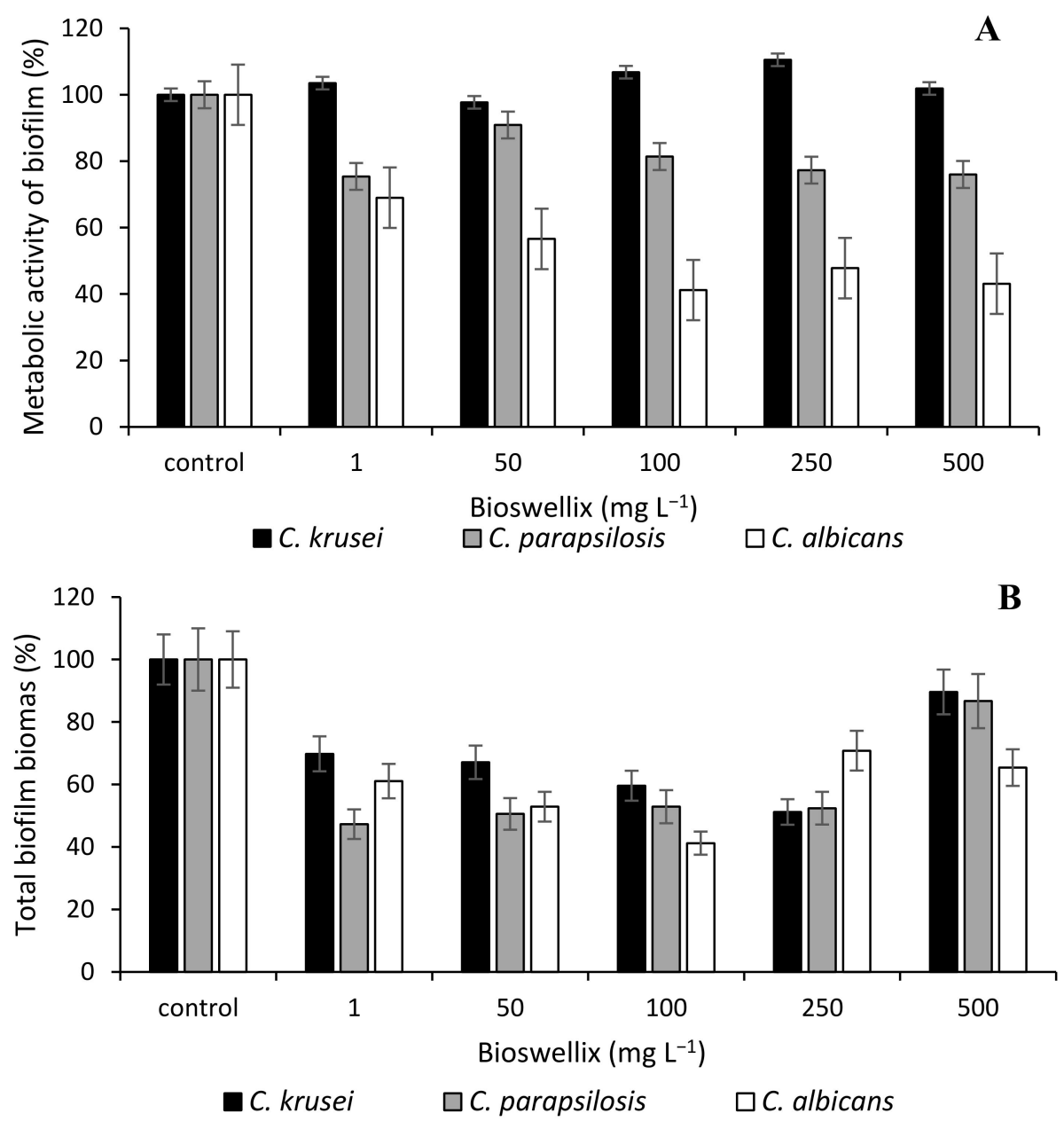

Figure 1. Effect of Boswellia serrata extract Bioswellix on C. albicans ATCC 2091, C. parapsilosis CCM 8260 and C. krusei CCM 8271. Biofilm metabolic activity (A); total biofilm biomass (B); control 100\% (no agent). Error bars represent standard deviation.

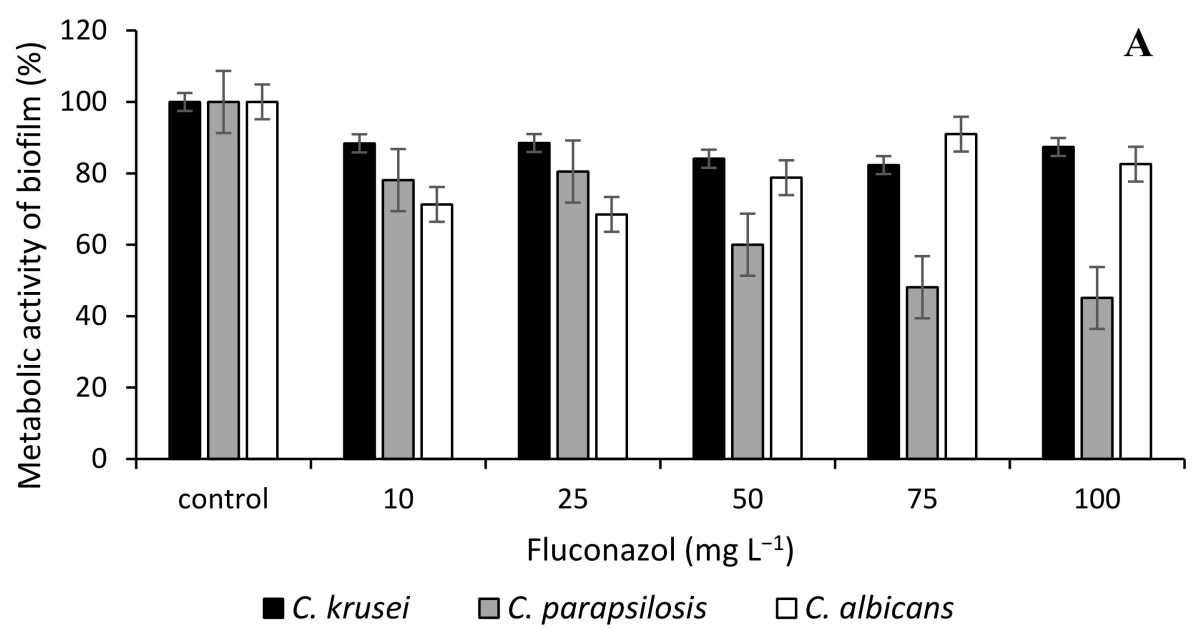

Figure 2. Cont. 


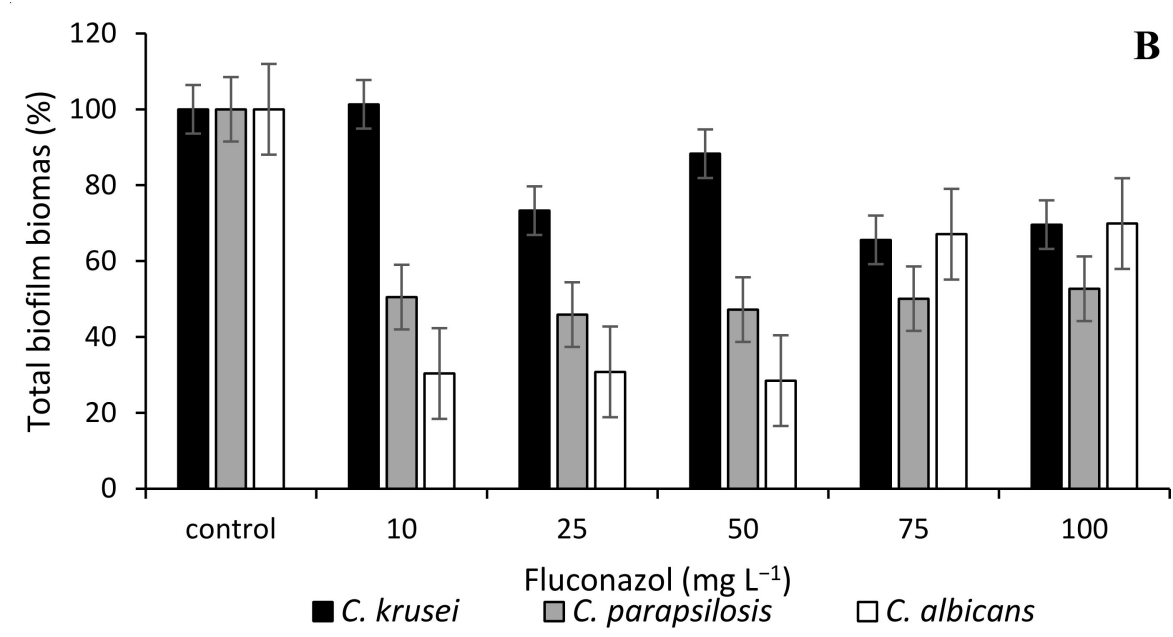

Figure 2. Effect of fluconazole on C. albicans ATCC 2091, C. parapsilosis CCM 8260 and C. krusei CCM 8271. Biofilm metabolic activity of (A); total biofilm biomass (B); control 100\% (no agent). Error bars represent standard deviation.

The filamentous form of $C$. albicans is considered to be one of the major virulence factors that is responsible for the easier adhesion of cells to surfaces [76]. Figures 3 and 4 demonstrate the morphology of $C$. albicans cells in the presence of boswellic acids contained in Bioswellix and in the presence of fluconazole ( $24 \mathrm{~h}$ old biofilm). Unfortunately, it is not possible to state that boswellic acids inhibit the virulence of $C$. albicans. Future studies should include different incubation times and a more efficacious microscopy analysis-for example, a scanning electron microscopy to conclude that $C$. albicans exposed to Bioswellix remains oval, does not change and does not undergo transition to hyphal form.

As can be seen from our results and from the research by Jenks et al. and Katragkou et al. [77,78], it is not problematic to eliminate planktonic cells (MIC) but it is problematic to eradicate cells in the form of a highly structured biofilm. Highly dangerous infections need not be caused only by C. albicans, which is said to be the fourth most common cause of nosocomial infections [79]; it is increasingly important to focus research on non-albicans Candida spp. such as C. parapsilosis, C. tropicalis, C. krusei and C. auris, which are increasingly common causes of nosocomial diseases $[80,81]$. It is clear from the reviews published in 2021 that the effective concentrations of various plant extracts or essential oils for inhibiting biofilm formation are in multiples of the MIC for suspension cells $[57,75,82,83]$. Nor do multiple MIC concentrations inhibit biofilm formation by $100 \%$. The mechanisms of action of natural substances on Candida cells are often not exactly known but are associated with anti-virulence activities, anti-biofilm properties, cell wall inhibition or cell membrane synthesis and induction of cell apoptosis [68]. Due to the effects of natural substances on the Candida genus, it is suitable to test them together with antifungal drugs. According to current studies, these combinations have a synergistic effect, with effects on efflux pumps and on ergosterol synthesis being their most common mechanisms of action [68]. 


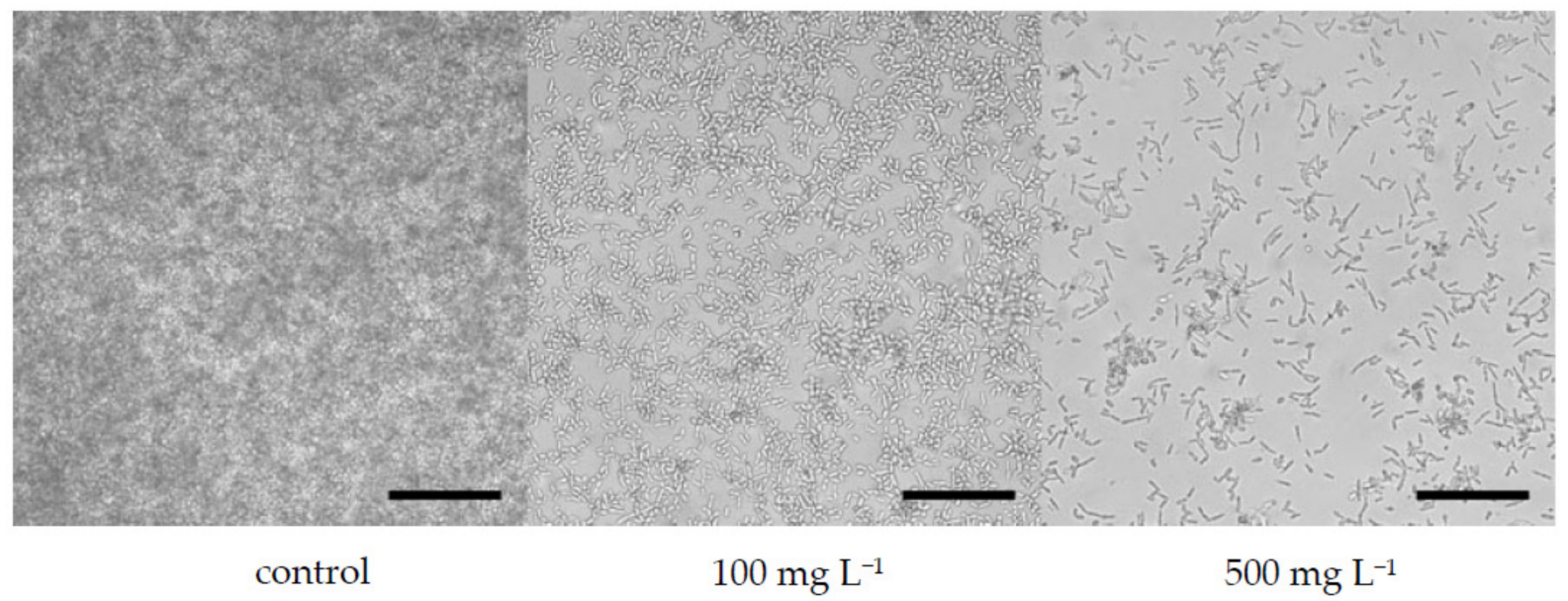

Figure 3. Effect of Bioswellix on C. albicans ATCC 2091 biofilm formation (visualized by a Cellavista device), scale bar $100 \mu \mathrm{m}$.

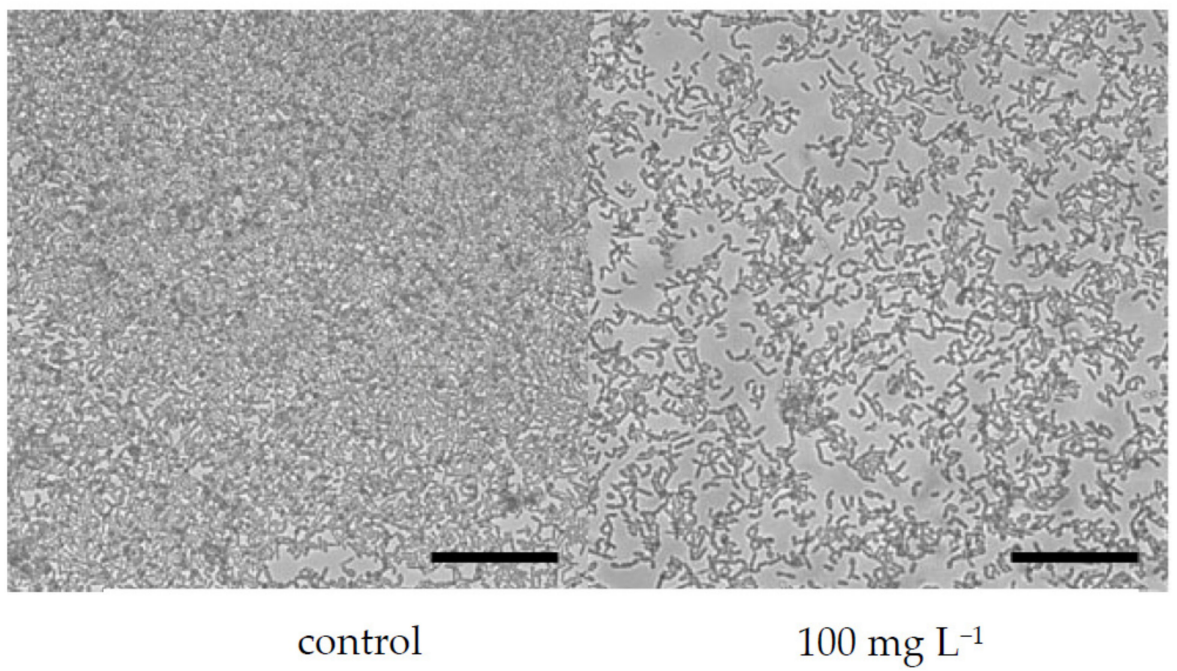

Figure 4. Effect of fluconazole on C. albicans ATCC 2091 biofilm formation (visualized by a Cellavista device), scale bar $100 \mu \mathrm{m}$.

\section{Conclusions}

Antibiofilm activity of boswellic acids currently attracts considerable attention, and our study expands the issue with new knowledge. Given the results of this work, it seems that boswellic acids could act as antifungal drugs against suspension populations of Candida yeasts, including Candida albicans. Potentially, their effect in combination with antifungal drugs should be studied in search of synergy, due to the boswellic acids increasing the release of cells from biofilm.

Author Contributions: P.J. wrote the manuscript and designed the experiments; M.V. and J.M. carried out experiments and analyzed data; K.L. contributed to manuscript writing and editing; I.K. and K.D. supervised work, performed analysis and took the lead in writing the manuscript. All authors have read and agreed to the published version of the manuscript.

Funding: This research received no external funding.

Institutional Review Board Statement: Not applicable.

Informed Consent Statement: Not applicable.

Data Availability Statement: All relevant data are contained within this article. 
Conflicts of Interest: The authors declare no conflict of interest. The funders had no role in the design of the study; in the collection, analyses, or interpretation of data; in the writing of the manuscript; or in the decision to publish the results.

\section{References}

1. Abdallah, M.; Benoliel, C.; Drider, D.; Dhulster, P.; Chihib, N.-E. Biofilm formation and persistence on abiotic surfaces in the context of food and medical environments. Arch. Microbiol. 2014, 196, 453-472. [CrossRef]

2. Kašparová, P.; Mat'átková, O.; Čejková, A. Can the advantages of the genus Candida exceed the strong pathogenesis of some of its species? Chem. Lett. 2019, 113, 415-421.

3. Schindler, J. The Universe; Vesmír, s.r.o.: Prague, Czech Republic, 2001.

4. Bridier, A.; Sanchez-Vizuete, P.; Guilbaud, M.; Piard, J.-C.; Naïtali, M.; Briandet, R. Biofilm-associated persistence of food-borne pathogens. Food Microbiol. 2015, 45, 167-178. [CrossRef]

5. Melicharčíková, V. Sterilization and Disinfection in Healthcare; GRADA Publishing: Prague, Czech Republic, 1998.

6. Patocka, J. Biologically active pentacyclic triterpenes and their current medicine signification. J. Appl. Biomed. 2003, 1, 7-12. [CrossRef]

7. Kolouchová, I.; Melzoch, K.; Šmidrkal, J.; Filip, V. The content of resveratrol in vegetables and fruit. Chem. Lett. 2005, 99, 492-495.

8. Yauan, G.; Wahlqvist, M.; He, G.; Yang, M.; Li, D. Natural products and anti inflammatory activity. Asia Pac. J. Clin. Nutr. 2006, 15, 143.

9. Etzel, R. Use of Incense in the Treatment of Alzheimer's. Disease Patent US720975A, 24 February 1998.

10. Tsukada, T.; Nakashima, K.; Shirakawa, S. Arachidonate 5 lipoxygenase inhibitors show potent antiproliferative effects on human leukemia cell lines. Biochem. Biophys. Res. Commun. 1986, 140, 832-836. [CrossRef]

11. Huang, M.T.; Badmaev, V.; Ding, Y.; Liu, Y.; Xie, J.G.; Ho, C.T. Anti tumor and anti carcinogenic activities of triterpenoid, beta boswellic acid. Biofactors 2000, 13, 225-230. [CrossRef]

12. Gupta, I.; Gupta, V.; Parihar, A.; Gupta, S.; Lüdtke, R.; Safayhi, H.; Ammon, H.P. Effects of Boswellia serrata gum resin in patients with bronchial asthma. Results of a double blind, placebo controlled, 6 week clinical study. Eur. J. Med. Res. 1998, 3, 511-514.

13. Krieglstein, C.F.; Anthoni, C.; Rijcken, E.J.; Laukötter, M.; Spiegel, H.U.; Boden, S.E.; Schweizer, S.; Safayhi, H.; Senninger, N.; Schürmann, G. Acetyl 11 keto beta boswellic acid, a constituent of a herbal medicine from Boswellia serrata resin, attenuates experimental ileitis. Int. J. Colorectal Dis. 2001, 16, 88-95. [CrossRef] [PubMed]

14. Ravanan, P.; Singh, S.K.; Rao, G.S.; Kondaiah, P. Growth inhibitory, apoptotic and anti inflammatory activities displayed by a novel modified triterpenoid, cyano enone of methyl boswellates. J. Biosci. 2011, 36, 297-307. [CrossRef] [PubMed]

15. Flavin, D.F. A lipoxygenase inhibitor in breast cancer brain metastases. J. Neurooncol. 2007, 82, 91-93. [CrossRef]

16. Gyawali, R.; Ibrahim, S.A. Natural products as antimicrobial agents. Food Control 2014, 46, 412-429. [CrossRef]

17. Safayhi, H.; Rall, B.; Sailer, E.R. Ammon, H.P. Inhibition by boswellic acids of human leukocyte elastase. J. Pharm. Exp. Ther. 1997, 281, 460-463.

18. Ammon, H.P.; Mack, T.; Singh, G.B.; Safayhi, H. Inhibition of leukotriene B4 formation in rat peritoneal neutrophils by an ethanolic extract of the gum resin exudate of Boswellia Serrata. Planta Med. 1991, 57, 203-207. [CrossRef]

19. Camarda, L.; Dayton, T.; Di Stefano, V.; Pitonzo, R.; Schillaci, D. Chemical composition and antimicrobial activity of some oleogum resin essential oils from Boswellia spp. (Burseraceae). Ann. Chim. 2007, 97, 837-844. [CrossRef]

20. Schillaci, D.; Arizza, V.; Dayton, T.; Camarda, L.; Di Stefano, V. In vitro anti- biofilm activity of Boswellia spp. oleogum resin essential oils. Lett. Appl. Microbiol. 2008, 47, 433-438. [CrossRef]

21. Raja, A.F.; Ali, F.; Khan, I.A.; Shawl, A.S.; Arora, D.S.; Shah, B.A.; Taneja, S.C. Antistaphylococcal and biofilm inhibitory activities of acetyl-11-keto- $\beta$-boswellic acid from Boswellia serrata. BMC Microbiol. 2011, 11, 54. [CrossRef]

22. Ammon, H.P.T. Boswellic Acids in chronic inflammatory diseases. Planta Med. 2006, 72, 1100-1116. [CrossRef]

23. Siddiqui, M.Z. Boswellia serrata, a potential antiinflammatory agent. Indian J. Pharm. Sci. 2011, 73, 255-261. [PubMed]

24. Silva, S.; Negri, M.; Henriques, M.; Oliveira, R.; Williams, D.W.; Azeredo, J. Adherence and biofilm formation of non-Candida albicans Candida species. Trends Microbiol. 2011, 19, 241-247. [CrossRef]

25. Trofa, D.; Gacser, A.; Nosanchuk, J.D. Candida parapsilosis, an Emerging Fungal Pathogen. Clin. Microbiol. Rev. 2008, 21, 606-625. [CrossRef]

26. Ghannoum, M.A.; Rice, L.B. Antifungal agents: Mode of action, mechanisms of resistance, and correlation of these mechanisms with bacterial resistance. Clin. Microbiol. Rev. 1999, 12, 501-517. [CrossRef] [PubMed]

27. Vitale, R.G. Role of Antifungal Combinations in difficult to treat Candida infections. J. Fungi 2021, 7, 731. [CrossRef] [PubMed]

28. Kato, H.; Hagihara, M.; Shibata, Y.; Asai, N.; Yamagishi, Y.; Iwamoto, T.; Mikamo, H. Comparison of mortality between echinocandins and polyenes for an initial treatment of candidemia: A systematic review and meta-analysis. J. Infect. Chemother. 2021, 27, 1562-1570. [CrossRef]

29. Baillie, G.S.; Douglas, L.J. Matrix polymers of Candida biofilms and their possible role in biofilm resistance to antifungal agents. J. Antimicrob. Chemother. 2000, 46, 397-403. [CrossRef] [PubMed]

30. Mukherjee, P.K.; Chandra, J.; Kuhn, D.M.; Ghannoum, M.A. Mechanism of fluconazole resistance in Candida albicans biofilms: Phase-specific role of efflux pumps and membrane sterols. Infect. Immun. 2003, 71, 4333-4340. [CrossRef] 
31. Tobudic, S.; Kratzer, C.; Lassnigg, A.; Presterl, E. Antifungal susceptibility of Candida albicans in biofilms. Mycoses 2012, 55, 199-204. [CrossRef]

32. Singh, B.; Upreti, D.; Singh, B.; Pandey, G.; Verma, S.; Roy, S.; Naqvi, A.; Rawat, A. Quercetin sensitizes fluconazole-resistant Candida albicans to induce apoptotic cell death by modulating quorum sensing. Antimicrob. Agents Chemother. 2015, 59, $2153-2168$. [CrossRef]

33. Andrews, H.P. Determination of minimum inhibitory concentrations. J. Antimicrob Chemother. 2001, 48, 5-16. [CrossRef]

34. Li, X.; Yan, Z.; Xu, J. Quantitative variation of biofilms among strains in natural populations of Candida albicans. Microbiology 2003, 149, 353-362. [CrossRef]

35. Sabaeifard, P.; Abdi-Ali, A.; Soudi, M.R.; Dinarvand, R. Optimization of tetrazolium salt assay for Pseudomonas aeruginosa biofilm using microtiter plate method. J. Microbiol. Methods 2014, 105, 134-140. [CrossRef]

36. Riss, T.; Moravec, R.; Niles, A.; Benink, H.; Worzella, T.; Minor, L. Cell Viability Assays. Assay Guidance Manual [Internet]; Eli Lilly \& Company and the National Center for Advancing Translational Sciences: Bethesda, MD, USA, 2004.

37. Paldrychová, M.; Kolouchová, I.; Vaňková, E.; Mat'átková, O.; Šmidrkal, J.; Krmela, A.; Schulzová, V.; Hajšlová, J.; Masák, J. Effect of resveratrol and regrapex-R-forte on Trichosporon cutaneum biofilm. Folia Microbiol. 2019, 64, 73-81. [CrossRef] [PubMed]

38. Stanbury, R.M.; Graham, E.M. Systemic corticosteroid therapy side effects and their management. Br. J. Ophthalmol. 1998, 82, 704-708. [CrossRef]

39. Wiseman, A.C. Immunosuppressive medications. Clin. J. Am. Soc. Nephrol. 2016, 11, 332-343. [CrossRef]

40. Kazemi, S.; Shirzad, H.; Rafieian-Kopaei, M. Recent findings in molecular basis of inflammation and anti-inflammatory plants. Curr. Pharm. Des. 2018, 24, 1551-1562. [CrossRef]

41. Fürst, R.; Zündorf, I. Plant-derived anti-inflammatory compounds: Hopes and disappointments regarding the translation of preclinical knowledge into clinical progress. Mediat. Inflamm. 2014, 2014, 146832. [CrossRef]

42. Krcmery, V.C. Antifungal Chemotherapeutics. Med. Princ. Pract. 2005, 14, 125-135. [CrossRef]

43. Krausová, L.; Grim, J.; Pávek, P. Azolová antimykotika: Mechanizmy lékových interakcí. Klin. Farmakol. Farm. 2009, 23, 86-89.

44. Afrin, S.R.; Islam, M.R.; Proma, N.M.; Shorna, M.K.; Akbar, S.; Hossain, M.K. Quantitative screening of phytochemicals and pharmacological attributions of the leaves and stem barks of Macropanax dispermus (Araliaceae) in treating the inflammation and arthritis. J. Herbmed. Pharmacol. 2020, 10, 75-83. [CrossRef]

45. Al Qaraghuli, M.M.; Alzahrani, A.R.; Niwasabutra, K.; Obeid, M.A.; Ferro, V.A. Where traditional drug discovery meets modern technology in the quest for new drugs. Ann. Pharmacol. Pharm. 2017, 2, 1-5.

46. Mukherjee, P.K. Evidence-Based Validation of Herbal Medicine; Elsevier: Boston, MA, USA, 2015.

47. Hamza, M.; Nadir, M.; Mehmood, N.; Farooq, A. In vitro effectiveness of triterpenoids and their synergistic effect with antibiotics against Staphylococcus aureus strains. Indian J. Pharmacol. 2016, 48, 710-714. [CrossRef] [PubMed]

48. Roy, N.K.; Parama, D.; Banik, K.; Bordoloi, D.; Devi, A.K.; Thakur, K.K.; Padmavathi, G.; Shakibaei, M.; Fan, L.; Sethi, G. An update on pharmacological potential of boswellic acids against chronic diseases. Int. J. Mol. Sci. 2019, 20, 4101. [CrossRef] [PubMed]

49. Wang, Q.; Pan, X.; Wong, H.; Wagner, C.; Lahey, L.; Robinson, W.; Sokolove, J. Oral and topical boswellic acid attenuates mouse osteoarthritis. Osteoarth. Cartil. 2017, 22, 128-132. [CrossRef] [PubMed]

50. Harsha, K.; Shreya, K. Topical Nanoemmigel Formulation of Boswellia serrata. Indian Pharm. Sci. 2018, 80, 261-267. [CrossRef]

51. Bertocchi, M.; Isani, G.; Medici, F.; Andreani, G.; Tubon Usca, I.; Roncada, P.; Forni, M.; Bernardini, C. Anti-inflammatory activity of Boswellia serrata extracts: An in vitro study on porcine aortic endothelial cells. Oxidative Med. Cell Longev. 2018, 2018, 2504305. [CrossRef]

52. Kumar, R.; Singh, S.; Saksena, A.K.; Pal, R.; Jaiswal, R.; Kumar, R. Effect of Boswellia serrata extract on acute inflammatory parameters and tumor necrosis factor-a in complete Freund's adjuvant-induced animal model of rheumatoid arthritis. Int. J. Appl. Basic Med. Res. 2019, 9, 100-106. [CrossRef]

53. Ebrahimpour, S.; Fazeli, M.; Mehri, S.; Taherianfard, M.; Hosseinzadeh, H. Boswellic acid improves cognitive function in a rat model through its antioxidant activity:-Neuroprotective effect of Boswellic acid. J. Pharmacopunct. 2017, 20, 10-17.

54. Ismail, S.M.; Rao, S.; Bhaskar, M. Evaluation of antiinflammatory activity of Boswellia serrata on carrageenan induced paw edema in albino Wistar rats. Int. J. Res. Med. Sci. 2016, 4, 2980-2986. [CrossRef]

55. Lv, M.; Shao, S.; Zhang, Q.; Zhuang, X.; Qiao, T. Acetyl-11-Keto-b-Boswellic Acid Exerts the Anti-Cancer Effects via Cell Cycle Arrest, Apoptosis Induction and Autophagy Suppression in Non-Small Cell Lung Cancer Cells. OncoTargets Ther. 2020, 13, 733-744. [CrossRef]

56. Büchele, B.; Simmet, T. Analysis of 12 different pentacyclic triterpenic acids from frankincense in human plasma by highperformance liquid chromatography and photodiode array detection. J. Chromatogr. B Analyt. Technol. Biomed. Life Sci. 2003, 795, 355-362. [CrossRef]

57. Karpinski, T.M.; Ozarowski, M.; Seremak-Mrozikiewicz, A.; Wolski, H.; Adamczak, A. plant preparations and compounds with activities against biofilms formed by Candida spp. J. Fungi 2021, 7, 360. [CrossRef] [PubMed]

58. Arumugam, G.; Rajendran, R.; Syed, N.; Ramanathan, K.S. Anti-candidal and anti-virulence efficiency of selected seaweeds againstazole resistance Candida albicans. Biocatal. Agric. Biotechnol. 2019, 20, 101195. [CrossRef]

59. Rajkowska, K.; Nowicka-Krawczyk, P.; Kunicka-Styczynska, A. Efect of clove and thyme essential oils on Candida biofilm formation and the oil distribution in yeast cells. Molecules 2019, 24, 1954. [CrossRef] 
60. Sharma, M.; Manoharlal, R.; Negi, A.S.; Prasad, R. Synergistic anticandidal activity of pure polyphenol curcumin I in combination with azoles and polyenes generates reactive oxygen species leading to apoptosis. FEMS Yeast Res. 2010, 10, 570-578. [CrossRef]

61. Choonharuangdej, S.; Srithavaj, T.; Thummawanit, S. Fungicidal and inhibitory efficacy of cinnamon and lemongrass essential oils on Candida albicans biofilm established on acrylic resin: An in vitro study. J. Prosthet. Dent. 2021, 125, 707.e1-707.e6. [CrossRef]

62. Freires, I.A.; Murata, R.M.; Furletti, V.F.; Sartoratto, A.; Alencar, S.; de Alencar, S.M.; Figueira, G.M.; de Oliveira Rodrigues, J.A.; Duarte, M.C.; Rosalen, P.L. Coriandrum sativum L. (Coriander) Essential oil: Antifungal activity and mode of action on Candida spp., and molecular targets affected in human whole-genome expression. PLoS ONE 2014, 9, e099086. [CrossRef]

63. Barbieri, D.S.; Tonial, F.; Lopez, P.V.; Sales Maia, B.H.; Santos, G.D.; Ribas, M.O.; Glienke, C.; Vicente, V.A. Antiadherent activity of Schinus terebinthifolius and Croton urucurana extracts on in vitro biofilm formation of Candida albicans and Streptococcus mutans. Arch. Oral. Biol. 2014, 59, 887-896. [CrossRef] [PubMed]

64. Zago, P.M.W.; Dos Santos Castelo Branco, S.J.; de Albuquerque Bogea Fecury, L.; Carvalho, L.T.; Rocha, C.Q.; Madeira, P.L.B.; de Sousa, E.M.; de Siqueira, F.S.F.; Paschoal, M.A.B.; Diniz, R.S.; et al. Anti-biofilm action of Chenopodium ambrosioides extract, cytotoxic potential and effects on acrylic denture surface. Front. Microbiol. 2019, 10, 1724. [CrossRef] [PubMed]

65. Madeira, P.L.B.; Carvalho, L.T.; Paschoal, M.; de Sousa, E.M.; Moffa, E.; da Silva, M.A.S.; Tavarez, R.R.; Gonçalves, L. In vitro effects of lemongrass extract on Candida albicans biofilms, human cells viability, and denture surface. Front. Cell Infect. Microbiol. 2016, 6, 71. [CrossRef] [PubMed]

66. Quatrin, P.M.; Verdi, C.M.; de Souza, M.E.; de Godoi, S.N.; Klein, B.; Gundel, A.; Wagner, R.; Vaucher, R.A.; Ourique, A.; Santos, R.C. Antimicrobial and antibiofilm activities of nanoemulsions containing Eucalyptus globulus oil against Pseudomonas aeruginosa and Candida spp. Microb. Pathog. 2017, 112, 230-242. [CrossRef]

67. Salete, M.F.B.; Galvo, L.C.C.; Goes, V.F.F.; Sartoratto, A.; Figueira, G.; Rehder, V.L.; Alencar, S.M.; Duarte, R.M.; Rosalen, P.L.; Duarte, M.C. Action of essential oils from Brazilian native and exotic medicinal species on oral biofilms. BMC Complement. Altern. Med. 2014, 14, 451.

68. Sun, F.-J.; Li, M.; Gu, L.; Wang, M.-L.; Yang, M.-H. Recent progress on anti-Candida natural products. Chin. J. Nat. Med. 2021, 19, 561-579. [CrossRef]

69. Weckesser, S.; Engel, K.; Simon-Haarhaus, B.; Wittmer, A.; Pelz, K.; Schempp, C.M. Screening of plant extracts for antimicrobial activity against bacteria and yeasts with dermatological relevance. Phytomedicine 2017, 14, 508-516. [CrossRef] [PubMed]

70. Vahabi, S.; Hakemi-Vala, M.; Gholami, S. In vitro antibacterial effect of hydroalcoholic extract of Lawsonia inermis, Malva sylvestris, and Boswellia serrata on Aggregatibacter actinomycetemcomitans. Adv. Biomed. Res. 2019, 8, 22. [CrossRef] [PubMed]

71. Sadhasivam, S.; Palanivel, S.; Ghosh, S. Synergistic antimicrobial activity of Boswellia serrata Roxb. ex Colebr. (Burseraceae) essential oil with various azoles against pathogens associated with skin, scalp and nail infections. Lett. Appl. Microbiol. 2016, 63, 495-501. [CrossRef]

72. Maiolo, E.M.; Tafin, U.F.; Borens, O.; Trampuz, A. Activities of fluconazole, caspofungin, anidulafungin, and amphotericin b on planktonic and biofilm Candida species determined by microcalorimetry. Antimicrob. Agents Chemother. 2014, 58, $2709-2717$. [CrossRef] [PubMed]

73. Swinne, D.; Watelle, M.; Nolard, N. In vitro activities of voriconazole, fluconazole, itraconazole and amphotericin B against non Candida albicans yeast isolates. Rev. Iberoam. Micol. 2005, 22, 24-28. [CrossRef]

74. Peixoto, L.R.; Rosalen, P.L.; Ferreira, G.L.S.; Freires, I.A.; de Carvalho, F.G.; Castellano, L.R.; de Castro, R.D. Antifungal activity, mode of action and anti-biofilm effects of Laurus nobilis Linnaeus essential oil against Candida spp. Arch. Oral. Biol. 2017, 73, 179-185. [CrossRef]

75. Butassi, E.; Svetaz, L.; Carpinella, M.C.; Efferth, T.; Zacchino, S. Fungal biofilms as a valuable target for the discovery of natural products that cope with the resistance of medically important fungi-Latest findings. Antibiotics 2021, 10, 1053. [CrossRef]

76. Khan, F.; Bamunuarachchic, N.I.; Tabassum, N.; Jo, D.-M.; Khan, M.M.; Kim, Y.-M. Suppression of hyphal formation and virulence of Candida albicans by natural and synthetic compounds. Biofouling 2021, 37, 626-655. [CrossRef]

77. Jenks, J.D.; Cornely, O.A.; Chen, S.C.A.; Thompson III, G.R.; Hoenigl, M. Breakthrough invasive fungal infections: Who is at risk? Mycoses 2020, 63, 1021-1032. [CrossRef]

78. Katragkou, A.; Roilides, E.; Walsh, T.J. Role of echinocandins in fungal biofilm-related disease: Vascular catheter-related infections, immunomodulation, and mucosal surfaces. Clin. Infect. Dis. 2015, 61, 622-629. [CrossRef]

79. Pfaller, M.A.; Diekema, D.J. Epidemiology of invasive candidiasis: A persistent public health problem. Clin. Microbiol Rev. 2007, 20, 133-163. [CrossRef]

80. Borjian Boroujeni, Z.; Shamsaei, S.; Yarahmadi, M.; Getso, M.I.; Salimi Khorashad, A.; Haghighi, L.; Raissi, V.; Zareei, M.; Saleh Mohammadzade, A.; Moqarabzadeh, V.; et al. Distribution of invasive fungal infections: Molecular epidemiology, etiology, clinical conditions, diagnosis and risk factors: A 3-year experience with 490 patients under intensive care. Microb. Pathog. 2021, 152, 104616. [CrossRef]

81. McCarthy, M.W.; Walsh, T.J. Drug development challenges and strategies to address emerging and resistant fungal pathogens. Expert Rev. Anti Infect Ther. 2017, 15, 577-584. [CrossRef] [PubMed]

82. Guimarães, R.; Milho, C.; Liberal, A.; Silva, J.; Fonseca, C.; Barbosa, A.; Ferreira, I.C.F.R.; Alves, M.J.; Barros, L. Antibiofilm Potential of Medicinal Plants against Candida spp. Oral Biofilms: A Review. Antibiotics 2021, 10, 1142. [CrossRef] [PubMed]

83. Alam, M.Z.; Khan, M.S.A. Phytomedicine from Middle Eastern countries: An alternative remedy to modern medicine against Candida spp. infection. Evid.-Based Complement. Altern. Med. 2021, 2021, 6694876. [CrossRef] 